\title{
Paternalism versus autonomy: medical opinion and ethical questions in the treatment of defective neonates
}

\author{
Peter Ferguson Law Student, University of Edinburgh
}

\section{Author's abstract}

The author considers the notion that the doctor is the sole arbiter of what happens to a defective neonate; how this is a logical confusion of scientific assessment with value judgment. The utilitarian concept found in a democracy is taken to be the superior source of ethics which ought to guide doctors. Finally, the logical conclusion is claimed to be that legislation alone will effectively enunciate society's standards.

A case in I98I (I), where the Court of Appeal decided in a wardship action that an operation ought to go ahead to preserve the life of a mongol child, and the cause célèbre of 'the Arthur Case' (2) raised an interesting question regarding the conflict which arises between two obviously antithetic views, namely, paternalism (ie, 'the doctor knows best') and the principle of self-determination or autonomy, which in the case of an infant defective, which the cases involved, does not mean the neonate's right to decide but only the negative right of not being dealt with as, and only as, the physician, in his or her judgment, thinks best. Thus, the cases go to the very heart of the I 980 Reith lecturer's argument (3) and the criticisms made of his lectures (4).

The question can be posed: To what extent is the doctor the sole arbiter of right in what happens to the defective infant - say a child suffering from Down's syndrome or a case of gross spina bifida? There is one view which states that the doctor knows most and is thus ably equipped to decide on life or death; but the negative principle of autonomy holds that this is not the case.

The problem is really one of mixing and confusing two discrete concepts: on the one hand, the concept of the medical deformities from which the infant is suffering and which the doctor alone is qualified adequately to diagnose; and, on the'other hand, the notion of how this must be viewed as determining what will happen to the child. There are those who run these two separate categories together and arrive at the decision that the

\section{Key words}

Law and medical ethics; severely handicapped infants; legislated morality; paternalism; autonomy. doctor can rightly decide the question which the Court $\vec{\omega}$ of Appeal (I) actually took upon itself to determine.

But, as has been said (5), 'the decision cannot be just $\Phi$ a medical one ... there is also the moral question of 6 whether, given all this [medical knowledge], it can be right to decide for the death of the baby'.

It is therefore obvious that it is firstly a matter of $\frac{\text { O }}{3}$ informed medical opinion: How severe is the spina bifida? To what extent is the infant mentally handicapped? And, secondly, a question of ethics: Is it right to kill it or let it die?

And at this point, as Kennedy rightly asks, and we $\vec{\varnothing}$ all must ask, the question is raised: Why should the ethical views of a doctor prevail over society's views? According to the paternalistic model, the doctor's views are superior because he knows best - but he truly only knows his medicine best. As the autonomy of the child means its right not to be dealt with only as the $\mathbb{Q}$ doctor thinks fit, it is thus imperative that society (of $\stackrel{2}{\Rightarrow}$ which the child is an equal member - as is the doctor) 응 dictate the standards of medical ethical decision- $\frac{}{5}$ making in order to prevent the imposition by the doctor of a paternalist view - and so prevent the infringement of the child's right to self-determination in the negative sense. While the child cannot actually decide, $\stackrel{\odot}{\circ}$ it is much more preferable that society choose than that 3 . the choice be made by a few people, whether they be doctors, parents or Nazi eugenicists.

Kennedy says a doctor has no more competence to decide than anyone else; his social, political or moral views are of equal standing with every other person's $-\frac{7}{0}$ but count for no more. This is because we live in a democracy with the shibboleth, 'one man, one vote'. N Just as the ethics of the Law Society are that legal part N of the entire ethics of society, so it is with medical N ethics (3).

All of what is said here hinges upon a very elemen-? tary rule of logic which David Hume was first to observe (6). One cannot deduce 'ought' from 'is'. Because a house is on fire and a woman is crying for help, it does not follow from this that a passer-by ought ${ }_{0}^{-}$ to help her. For where is the necessary connection? The two worlds of scientific fact (is) and morals (ought) are distinct entities in thought. And these separateo conceptual realms correspond to the discrete notions of medical fact and moral conclusions from the factualo analysis. 
As there is always a choice between the moral courses open (for if there were no choice, it would hardly be a question of moral dilemma: there would only be a single answer), there is no necessity that a certain course is the only one which is to be followed. The possession of medical knowledge does not mean that one possesses the key to the only possible course open; for there is no necessary moral conclusion to be deduced from the scientific facts.

Now, to return to the idea of democracy, it is a canon of our representative parliamentary democracy, that each man counts equally, so we have a utilitarian approach: a counting of heads. With no particular gift for ethical decisions, society by vote takes the decision.

Ronald Carson said of Kennedy's argument outlined above that he could not see 'how we all would arrive at such a consensus' (7) (my italics). But it must be objected (for Kennedy did not) that Carson is talking about everyone's agreeing. That is an unreasonable stumbling-block: of course, unanimity would be impossible but in our democracy (where unanimity is not required) we would not need universal consensus.

Now, having said that society decides, not doctors, there is the last question: What means will impose these standards and maintain them? It is generally believed (8) that the 'heavy hand of legislation' should not be brought to bear mainly because it is an area of opinion. But that is no real objection. All morals are a matter of opinion - and the Suicide Act 196I and Abortion Act 1967 are acceptable to most of us. Indeed, it is an illogical proposition that law should not be involved, though the explanation of why people feel this is easy to see. Put simply, people, especially the medical profession, do not want others looking over doctors' shoulders - for that would stifle initiative and shake the confidence of doctors themselves (as Denning, LJ observed (9)); and people do not want doctors hauled before the courts to undergo what Dr Arthur went through.

However, these are unrealistic desires. There are many people who stand to be accused of something illegal for which no guilt can properly be attached to them; but it is part of the democracy in which we live that everyone is at liberty to accuse another. The courts are the guardians of our rights which are guaranteed to us by law; to exclude their jurisdiction would be monstrous - and wrong.
It is all very well to say, as Kennedy does, that guidelines would serve just as well as law. But that really is to ignore the fact that with law (and it is a reason in favour of any law), one does not have to wait for people to come to their senses and set aside the jealousies which, as Kennedy explains, have prevented the medical profession from establishing these guidelines (I0). In a democracy the law is the ultimate expression of the people and so dictates for the good of society. Thus, it is to be regretted that the Criminal Law Revision Committee made no recommendations on euthanasia; especially, as they did not think themselves competent to do so (I I).

Legislation, or even judicial precedent, laying down society's chosen ethical position - which need not be unanimously arrived at but with which doctors would be required to comply - is thus far to be preferred over guidelines. And this is so because these guidelines would leave it open for Hume's essential distinction to be travestied as it is at present by some doctors who, it must be said, consider that their diagnosis of severe spina bifida is somehow of the same character as the decision on life or death.

(Commentary begins overleaf)

\section{References}

(1) Re B (A Minor) The Times law report 198I Aug 8: 1981 Weekly law reports I42I CA.

(2) R v Arthur The Times 198I Nov 6: I.

(3) Kennedy I. The unmasking of medicine. London: Allen and Unwin, 198I.

(4) The 1980 Reith Lectures - some reactions. Fournal of medical ethics 1981; 7: 173-211.

(5) Glover J. Letting people die. London review of books I982; $4: 3$.

(6) Hume D. A treatise of human nature. Oxford: Clarendon Press, I888: Book III, part I, final paragraph. See also: Lloyd of Hampstead, Lord. Introduction to jurisprudence. 4th edition; London: Stevens and Sons, 1979.

(7) Carson R A. Unmasking or demythologising medicine? Fournal of medical ethics $1981 ; 7$ : 185 .

(8) Williams G. Letter to The Times I98I Aug 13: 9. See also reference (3).

(9) Roe v Ministry of Health 1954: 2 All England law reports 131 at 139.

(I0) See reference (3) 159-160.

(II) Criminal Law Revision Committee. Offences against the person. I4th report, I980: Command No 7844; para I 15. 